Pomáhajúce profesie, roč. 4, č. 1, 2021, 14-29

\title{
UMIESTNENIE KONTROLY VO VZŤAHU KU ZDRAVIU, ADHERENCIA K LIEČBE A SOCIÁLNA OPORA PRI REKONVALESCENCII PACIENTOV PO PREKONANÍ CIEVNEJ MOZGOVEJ PRÍHODY
}

\author{
(Prehl'adová štúdia)
}

\author{
Boris Katrušín, Tomáš Sollár \\ Katedra psychologických vied FSVaZ UKF Nitra \\ boris.katrusin@ukf.sk; tsollar@ukf.sk
}

\begin{abstract}
Abstrakt: Kardiovaskulárne ochorenia predstavujú závažný spoločenský problém. Medzi najčastejšie patrí okrem ischemickej choroby srdca aj cievna mozgová príhoda. Jej dôsledky majú vplyv ako na fungovanie jednotlivca a jeho kvalitu života, tak aj na ekonomické zat'aženie štátov. Je preto dôležité hl'adat' spôsoby ako tomuto problému predchádzat' alebo minimalizovat' jeho dôsledky. Prehl'adová štúdia sa venovala psychologickým premeným: umiestneniu kontroly vo vzt'ahu $k$ zdraviu, adherencii, sociálnej opore, ako faktorom ktoré súvisia s efektivitou rekonvalescencie po prekonaní cievnej mozgovej príhody. Jej ciel'om bolo analyzovat' pôsobenie týchto premenných z hl'adiska teoretických východísk a posledných empirických zistení.
\end{abstract}

Kl'účové slová: cievna mozgová príhoda, rekonvalescencia, umiestnenie kontroly, adherencia, sociálna opora

\section{1 ÚVOD}

Kardiovaskulárne ochorenia (KVO) sú najčastejšou príčinou úmrtí vo svete. Najfrekventovanejšie ide o ischemickú chorobu srdca a cievnu mozgovú príhodu. Celosvetovo sú kardiovaskulárne choroby zodpovedné za približne 17,9 miliónov životov ročne. Na Slovensku umiera ročne na KVO, t.j. najmä ischemickú chorobu srdca a náhlu cievnu mozgovú príhodu (CMP) zhruba 23000 l'udí, čo predstavuje približne $40 \%$ úmrtí u mužov a $50 \%$ u žien). Na Slovensku je o viac než $100 \%$ vyššia úmrtnost' na kardiovaskulárne ochorenia v porovnaní s priemerom OECD (OECD, 2015). Len v Európskej Únii sa náklady spojené s KVO vyšplhajú na 210 miliárd euro (ECDS, 2017).

Účinná prevencia a rekonvalescencia dokážu týmto dopadom predchádzat' alebo ich minimalizovat'. Ako jeden z najúčinnejších spôsobov, ako predchádzat' výskytu KVO je podpora zdravého životného štýlu a redukcia rizikových faktorov. Medzi dôležité činitele, ktoré sa na ňom podpisujú sú kvalita a pestrost' stravy, fyzická aktivita a pohyb, s tým súvisiaca obezita (Brooker \& Mann, 2008), fajčenie (Mendis, Puska \& Norrving, 2011), požívanie alkoholu, drog, adherencia s liečbou, psychologické premenné (Cohen, Edmondson \& Kronish, 2015) a iné. Výskum ukazuje, že práve niektoré psychologické premenné sa môžu významne podiel'at' na úspešnosti prevencie liečby a rekonvalescencie zdravotného stavu pri KVO (Deary et al., 2010; Steptoe \& Chida, 2009; Kruper \& Denollet, 2018). Patria medzi ne umiestnenie kontroly vo vzt'ahu k zdraviu, adherencia a sociálna opora, ktoré si v nami prezentovanej prehl'adovej štúdii podrobnejšie rozoberieme. 
Výskum umiestnenia kontroly bol realizovaný v rôznych oblastiach zdravia, ktoré úzko súvisia s výskytom KVO napríklad: v súvislosti s obezitou (Ali \& Lindström, 2006), vysokým krvným tlakom (Gale et al., 2008), fyzickou aktivitou, fajčením (Kim, 2011; Steptoe \& Wardle, 2001) priamo s cievnou mozgovou príhodou (Zirk \& Storm, 2019; Hamzah \& Sugiyanto, 2014) rekonvalescenciou po prekonaní CMP (Zulkifly et al., 2015; Rapoliené et al., 2018), hypertenziou (Taher et al., 2015; Omeje \& Nebo, 2011) adherencie - dodržiavaním odporúčanej liečby lekára (Moreira, 2016; Nakamoto, Schulz \& Náfrádí, 2017). Výsledky prinášajú zmiešané údaje aj v oblasti prevencie, aj v oblasti efektivity rekonvalescencie vzhl'adom na konštrukt umiestnenia kontroly vo vzt’ahu $\mathrm{k}$ zdraviu.

Výskum v oblasti adherencie k medikamentóznej liečbe realizovaný na pacientoch s cievnou mozgovou príhodou prináša pomerne konzistentné výsledky napríklad v súvislosti s efektivitou rehabilitácie (Pishkhani et al., 2020), pretrvávaním psychických a fyzických dôsledkov (Cheiloudaki \& Alexopoulos, 2019; Han et al., 2020), výskytom nežiadúcich účikov liekov (Crayton, Wright \& Ashworth, 2018), rizikom opakovanej cievnej mozgovej príhody (Hajj et al., 2020) a funkčného stavu (Gunnes et al., 2019).

Sociálna opora sa ukazuje ako dôležitý faktor pri rekonvalescencii. Výsledky výskumov túto súvislost' preukazujú v oblasti respiračných ochorení (Chen et al., 2017; Lenferink, Palen \& Effing, 2018), onkologických ochorení (Usta, 2012; Gordner et al., 1996) gastroenterologických ochorení (Fu et al., 2020) ale aj kardiovaskulárnych ochorení (Glass et al. 1999; Tsouna-Hadjis et al., 2000; Bucholz, 2014; Blessing \& Oluwagbemiga, 2017)

Ciel'om prehl'adovej štúdie poskytnút' vhl'ad do vybraných premenných a ich súvislosti na základe realizovaných empirických zistení, akú úlohu zohráva umiestnenie kontroly, adherencia k liečbe a sociálna opora pri rekonvalescencii pacientov po prekonaní cievnej mozgovej príhody.

\section{METÓDY}

Pre naplnenie stanoveného ciel’a bolo potrebné preskúmat' dostupnú literatúru a publikovaný výskum v oblasti rekonvalescencie po prekonaní cievnej mozgovej príhody a vybraných premenných, ktoré sa podpisujú na jej efektivite. Pre vyhl'adávanie príslušných zdrojov sme zvolili klúčové slová $\mathrm{v}$ anglickom jazyku: cievna mozgová príhoda (stroke), rekonvalescencia (reconvalescence), adherencia (adherence), umiestnenie kontroly (locus of control), sociálna opora (social support). Pre zaradenie do našej štúdie museli zdroje splnit’ nasledujúce kritériá: využitie kvantitatívnych metód bádania, publikované v anglickom jazyku, minimálna vzorka 30 participantov. Štúdie ktoré nespĺnali toto kritérium, neboli do našej práce zaradené. 11 z 36 nájdených, publikovaných zdrojov spĺn̆alo tieto nároky. Tie boli d’alej analyzované z hl'adiska vzorky, metód vyhodnocovania kvantitatívnych dát, meracích nástrojov a kl'účových zistení.

\section{VÝSLEDKY}

\section{1 Umiestnenie kontroly a rekonvalescencia po prekonaní CMP}

Multidimenzionálne umiestnenie kontroly vo vzt’ahu k zdraviu vychádza z modelu od Hanny Levenson, avšak špecificky ho umiestnili do okruhov týkajúcich sa vnímania zdravia a choroby fokusovali Wallston a DeVellis (1978). Rovnako, ako všeobecné multidimenzionálne umiestnenie kontroly (MLoC) vypovedá o nešpecifických situáciách, vypovedá MHLoC konkrétne o miere, s akou jednotlivec chápe svet internalisticky alebo externalisticky $\mathrm{v}$ perspektíve faktorov ovplyvňujúcich zdravie človeka. Dimenzia Interného presvedčenia je demonštrovaná subjektívnym presvedčením človeka, nakol'ko je on sám zodpovedný za vlastné zdravie a nakol'ko je schopný ho v určitých intenciách ovplyvnit'. Naopak dimenzia externého presvedčenia vypovedá, 
nakol'ko je človek presvedčený, že za jeho zdravie sú zodpovedné vonkajšie vplyvy, ktoré sú mimo jeho kontroly. Externé presvedčenie má dve subdimenzie. Prvou, Chance - pod ktorú zarad'ujeme faktory náhodných udalostí, tie môžu byt' chápané ako náhoda, osud, št’astie/nešt'astie. A druhou subdimenziou je Powerfull others, pod ktorú zarad'ujeme faktory osôb, ktoré súvisia s naším zdravím a majú naň vplyv. Vplyvní ostatní môžu byt' osoby akými sú lekári, zdravotnícki pracovníci, blízke osoby a rodinný príslušníci. Každá dimenzia zachytáva a vysvetl'uje informácie týkajúce sa unikátnych častí vnímania zdravia človeka ako potvrdzuje výskum. Dimenzie medzi sebou len slabo korelujú (Jomeen \& Martin, 2005). Na základe informácii z realizovaných štúdií sa interné presvedčenie považuje za silnejší prediktor fyzického, aj psychického zdravia oproti externému (Gore et al., 2016). Aj ked' mnoho štúdií prináša rozporné výsledky (Kim, 2011; Ozcakir et al., 2014; Steptoe \& Wardle, 2001).

Na základe informácii z realizovaných štúdií sa odborná obec delí na dva protichodné tábory podl’a toho ktorý faktor považujú za silnejší prediktor fyzického, aj psychického zdravia - Interný vs. Externý (Gore et al., 2016; Kim, 2011; Ozcakir et al., 2014; Steptoe \& Wardle, 2001). Výsledky výskumov, napriek tomu že začínajú hovorit’ o určitom trende v zodpovedaní v tejto otázky, kde sa Internalizmus sa ukazuje ako klúčový v oblasti prevencie zdravotných problémov, je považovaný za salutogénny faktor, po vypuknutí ochorenia, pri následnej liečbe, rehabilitácii a rekonvalescencii sa ukazuje dôležitá dimenzia externá - Powerfull others (Moreira, Marques, Salomé, Da Cunha, Pinheiro, 2016; Nakamoto, Schulz, \& Na, 2017). Dimenzia Externalizmu - Chance sa vo všeobecnosti považuje skôr ako negatívny faktor ako $\mathrm{v}$ prípade prevencie, tak aj v prípade liečby rôznych zdravotných ochorení (Kim, 2011; Steptoe \& Wardle, 2001).

V súčasnosti existuje prevaha štúdií, ktorá dokazuje že Internalizmus je práve faktorom ako preventívnym, tak faktorom úspešnej liečby a rekonvalescencie po vypuknutí ochorenia (Ali \& Lindström, 2006). Potvrdenie tohto smeru bolo, v súvislosti s vysokým krvným tlakom (Gale et al., 2008), fyzickou aktivitou, fajčením (Kim, 2011, Steptoe \& Wardle, 2001), cievnou mozgovou príhodou (Zirk \& Storm, 2019, Hamzah \& Sugiyanto, 2014) rekonvalescenciou po prekonaní CMP (Zulkifly et al., 2015; Rapoliené et al., 2018), hypertenziou (Taher et al., 2015; Omeje \& Nebo, 2011) dodržiavaním odporúčanej liečby lekára (Moreira et al., 2016; Nakamoto, Schulz \& Na, 2017). Napriek tomu neexistuje jednotný záver a mnohé štúdie dlhodobo prinášajú zmiešané výsledky. Vo svojej prehl'adovej práci sa zameriame na konštatovania najnovších zistení v oblasti umiestnenia kontroly a rekonvalescencie po prekonaní cievnej mozgovej príhody.

Štúdia realizovaná v Indonézii na 32 pacientoch po prekonaní cievnej mozgovej príhody, experimentálne potvrdila vplyv interného umiestnenia kontroly na efektivitu rekonvalescencie. $V$ svojom intervenčnom programe zameranom na podporu interného presvedčenia, podporovala prostredníctvom poradenstva zameraného na samostatnost' pacientov vo vlastnej starostlivosti. Pacienti mali možnost' sami rozhodovat' o tom, kedy budú vykonávat' každodenné činnosti a vytvárat' si harmonogram: rehabilitáciu, stravovanie, hygienu a toaletu, odpočinok, mobilitu atd'. Funkčný stav pacientov bol meraný pomocou Barthelovho indexu (BI) pred a po absolvovaní intervenčného programu. Výsledky ukázali výrazný nárast funkčného stavu pacientov. Autori konštatujú, že posilňovanie interného umiestnenia kontroly podporuje sebadôveru pacienta, zvyšuje motiváciu čo sa prejavuje aj v motivácii rehabilitovat', znížit' svoju závislost' na ostatných a tak pomáha zlepšovat' rekonvalescenciu pacienta a urýchlenie uzdravenia (Hamzah \& Sugiyanto, 2015).

Väčšiu štúdiu uskutočnili výskumníci z univerzity Kebangsaanu Malajzijského medicínskeho centra. Výskumu sa zúčastnilo 180 pacientov 6 týždňov po prekonaní cievnej mozgovej príhody u ktorých nebola zasiahnutá oblast' kognície - tá bola meraná Addensbookovou kognitívnou skúškou. Ciel'om štúdie bolo zistit' vzt'ahy medzi multidimenzionálnym umiestnením kontroly 
(MLoC), post-traumatickým stresom (Impact of Event Scale - IES) a fyzickým funkčným stavom pacientov (Bathel Index of Activities of Daily Life). Výsledky hierarchickej regresnej analýzy odhalili, že interné umiestnenie kontroly ako prediktor bol schopný vysvetlit' $18 \%$ predpokladaného funkčného stavu pacientov $\left(R^{2}=0,18 ; p=0,001\right)$. Autori konštatujú, že vysoké skóre Interného umiestnenia kontroly pôsobí na fyzické fungovanie pacientov po prekonaní CMP, vd’aka individuálnej sebaúčinnosti, ktorá ich vedie k lepšiemu a rýchlejšiemu zotaveniu. Ak je jedinec presvedčený o tom, že sa môže zotavit’ predovšetkým vlastným úsilím, bude investovat' viac času a úsilia do činností, ktoré si rehabilitácia vyžaduje. Zatial' čo jedinci, ktorí majú externé presvedčenie, to je ako sa ukazuje viac spojené s náladou, vykazujú nižšie zapojenie do rehabilitačných programov čo môže súvisiet' práve s ich aktuálne prežívanými emóciami (Zulkifly et al., 2015).

Nedávna štúdia realizovaná na vzorke Čínskej vzorke skúmala vzt’ahy medzi umiestnením kontroly vo vzt’ahu ku zdraviu, sociálnou oporou, nádejou a self-managementom u pacientov po prekonaní cievnej mozgovej príhody. Vzorku tvorilo 300 pacientov Čínskej nemocnice tradičnej medicíny v provincii Tianjin. Premenné boli merané pomocou multidimenzionálneho dotazníka umiestnenia kontroly vo vzt'ahu k zdraviu (MHLoC), Herthovom Indexe nádeje (Herth Hope Index - HHI), Škálou sociálnej opory ( Social Support Assessment Scale - SSAS) a škálou správania self-managementu po prekonaní cievnej mozgovej príhody (Stroke Self-management Behavior Scale - SS-MBS). Výsledky ukázali pozitívny vzt’ah medzi interným presvedčením a self managementom po prekonaní CMP a negatívny vzt’ah medzi externým presvedčením a self-managementom po prekonaní CMP. Interné presvedčenie tiež pozitívne mediovalo vzt'ah medzi sociálnou oporou a self-managementom po prekonaní CMP (Lei, 2020).

V Európskom kontexte bola realizovaná štúdia v Litve, ktorá sa zaoberala multidimenzionálnym umiestnením kontroly vo vzt’ahu k zdraviu a výstupmi rehabilitácie, pričom autori sa zamerali aj na faktory veku a etapy rehabilitácie v ktorej sa jedinec nachádzal. Do štúdie bolo zaradených 30 pacientov po prekonaní cievnej mozgovej príhody. Premenné boli merané prostredníctvom dotazníka Multidimenzionálneho umiestnenia kontroly vo vzt’ahu k zdraviu (MHLoC), Barthelovho indexu každodenných aktivít (Barthel Index Activities of Daily Life) a sociodemografických otázok. Štúdia odhalila štatisticky významnú pozitívnu koreláciu medzi interným umiestnením kontroly na začiatku rehabilitácie a zvýšením funkčného stavu pacientov a nezávislosti na druhých l'ud'och. Okrem hlavných zistení autori poukazujú na to, že starší pacienti boli výrazne menej interne motivovaní než mladší pacienti. Taktiež sa ukázalo, že v procese (merania na začiatku a na konci) rehabilitácie sa zvýšilo interné presvedčenie pacientov a naopak externé presvedčenie sa znížilo (Rapoliené, 2018).

Tabul'ka č.1: Prehl’ad výskumov umiestnenia kontroly a rekonvalescencie po CMP.

\begin{tabular}{|l|l|l|}
\hline $\begin{array}{l}\text { Autor, rok, } \\
\text { krajina: }\end{array}$ & $\begin{array}{l}\text { Vzorka, meracie nástroje, } \\
\text { doba merania po CMP : }\end{array}$ & Typ štúdie a hlavné zistenia: \\
\hline $\begin{array}{l}\text { Hamzah } \\
\begin{array}{l}\text { Sugiyanto, } \\
(2015), \\
\text { Indonézia. }\end{array}\end{array}$ & $\begin{array}{l}\mathrm{N}=32, \\
\text { Barthel Index }\end{array}$ & $\begin{array}{l}\text { Experimentálna, } \\
\text { Výsledky ukázali, že posilňovanie } \\
\text { interného presvedčenia má vplyv na nárast } \\
\text { funkčného stavu a rekonvalescenciu } \\
\text { pacientov po CMP. }\end{array}$ \\
\hline
\end{tabular}




\begin{tabular}{|c|c|c|}
\hline $\begin{array}{l}\text { Zulkifly et al., } \\
\text { (2015), } \\
\text { Malajzia. }\end{array}$ & $\begin{array}{l}\mathrm{N}=180 \text {, } \\
\text { Multidimensional Locus of } \\
\text { Control, Impact of Event Scale } \\
\text { Barthel Index of Activities of } \\
\text { Daily Life. } \\
\text { Doba: } 6 \text { týždňov po prekonaní } \\
\text { CMP }\end{array}$ & $\begin{array}{l}\text { Korelačná, Regresná } \\
\text { Vysoké skóre Interného umiestnenia } \\
\text { kontroly predikuje lepšie fyzické } \\
\text { fungovanie pacientov po prekonaní CMP a } \\
\text { vedie k efektívnejšiemu zotaveniu }\end{array}$ \\
\hline $\begin{array}{l}\text { Lei et al., } \\
\text { (2020), Čína }\end{array}$ & $\begin{array}{l}\text { N=300 } \\
\text { Multidimensional health locus } \\
\text { of control, Herth Hope Index, } \\
\text { Social Support Assessment } \\
\text { Scale Stroke, Self-management } \\
\text { Behavior Scale } \\
\text { Doba: } 4 \text { týždne po prekonaní } \\
\text { CMP }\end{array}$ & $\begin{array}{l}\text { Korelačná, Mediačná } \\
\text { Interné presvedčenie pozitívne mediovalo } \\
\text { vzt'ah medzi sociálnou podporou a self- } \\
\text { managementom po prekonaní CMP. }\end{array}$ \\
\hline $\begin{array}{l}\text { Rapoliené, } \\
\text { (2018), Litva, }\end{array}$ & $\begin{array}{l}\mathrm{N}=30 \\
\text { Multidimensional Locus of } \\
\text { Control, Barthel Index } \\
\text { Activities of Daily Life. } \\
\begin{array}{l}\text { Doba: 12-16 týždňov po } \\
\text { prekonaní CMP }\end{array}\end{array}$ & $\begin{array}{l}\text { Korelačná, Komparačná } \\
\text { Pozitívny vzt’ah medzi interným } \\
\text { umiestnením kontroly na začiatku } \\
\text { rehabilitácie a zlepšením funkčného stavu } \\
\text { pacientova nezávislosti na druhých l'ud'och. } \\
\text { Starší pacienti sú výrazne menej interne } \\
\text { motivovaní než mladší pacienti. }\end{array}$ \\
\hline
\end{tabular}

Výsledky posledných štúdií realizované na pacientoch po prekonaní CMP sa teda prikláňajú ku zisteniam o internom presvedčení ako o faktore ktorý pozitívne vplýva na rekonvalescenciu. Autori venujúci sa tejto oblasti vyzývajú, že pre jasnejšie pochopenie toho, ako umiestnenie kontroly súvisí s rekonvalescenciou a dôsledkami cievnej mozgovej príhody je potrebné pokračovat' v d’alšom bádaní (Zirk \& Storm, 2019)

\subsection{Adherencia $k$ liečbe a rekonvalescencia po prekonaní CMP}

Svetová zdravotnícka organizácia (WHO, 2003), charakterizuje adherenciu ako rozsah v ktorom správanie osoby - užívanie liekov, dodržiavanie diety a/alebo uskutočnenie zmien životného štýlu, zodpovedá dohodnutým odporúčaniam poskytovatel'a zdravotnej starostlivosti. Širšie poňatie pojmu adherencie zahŕňa predovšetkým dôležitost' aktívneho zapojenia sa chorého do liečby, ktorý nie je iba pasívnym vykonávatel'om rozkazov, ale motivovaným spolupracovníkom, ktorý chápe význam ich dodržiavania

V staršej literatúre sa môžeme stretnút' s pojmom kompliancia (angl. compliance), ktorý skôr označoval ochotu ako motivovanost' a aktívne zapojenie. $\mathrm{V}$ súčasnej literatúre a výskume sa nahrádza práve pojmom adherencia. Tretím dôležitým pojmom $v$ tejto súvislosti je perzistencia. Tá vyjadruje nakol'ko je pacient schopný dlhodobo a správne užívat' medikáciu alebo dodržiavat' iný stanovený liečebný režim (Vráblik, 2012).

Problém nedostatočnej adherencie k liečbe sa týka všetkých pacientov. V prípade liečby vedúcej $\mathrm{k}$ potláčaniu symptómov sa non-adherentné správanie vyskytuje podstatne menej často než $\mathrm{v}$ prípade liečby chronických ochorení, kam patria práve KVO. Výsledky ukazujú, že v prípade KVO až $40 \%$ pacientov preruší liečbu do 2 rokov od jej zahájenia. Za riziko non-adherentného správania 
sa ukazuje aj vek, kedy l'udia mladší ako 30 rokov, prestávajú dodržiavat' liečbu a s ňou spojené opatrenia až $12 x$ častejšie, ako pacienti nad 50 rokov. Horšiu adherenciu tiež vykazujú muži, osoby s nižším vzdelaním a osoby s nižším socioekonomickým statusom (Vráblik, 2012). Súhrnne možno povedat', že nízka adherencia k liečbe KVO predstavuje vel'mi častý problém s vážnymi následkami.

Štúdia venujúca sa adherencii k medikácii a dôsledkom ischemickej cievnej mozgovej príhody bola realizovaná na Gréckej populácii 180 pacientov. Premenné boli merané sebavvýpoved'ovou škálou medikamentóznej adherencie (Medication Adherence Report Scale - MARS) a dotazníkom špecifickej kvality života po prekonaní CMP (Stroke Specific Quality of Life Questionnaire - SSQLQ). Výsledky ukázali že pacienti s optimálnou adherenciou ku liečbe vykazovali menej problémov vo vizuálne oblasti, psychickej oblasti a v oblasti kognitívných funkcií (Cheiloudaki \& Alexopoulos, 2019).

Brunejský autori realizovali výskum adherentného správania, nežiaducich účinkov medikácie a kvality života. Výskumnú vzorku tvorilo 76 pacientov Brunejského neurovedeckého centra pre liečbu a rehabilitáciu cievnej mozgovej príhody. Premenné boli merané Moriskyho škálou adherencie k medikácii a vytvoreným sebavýpoved'ovým dotazníkom zdravotnej kondície. Vsledky preukázali, že pacienti $\mathrm{s}$ vyššou adherenciou $\mathrm{k}$ liečbe vykazovali zlepšenie životného štýlu (pravidelné cvičenie) a vykazovali tiež menej nežiaducich účinkov súvisiacich s medikáciou a tiež sa u nich preukázalo menej nepríjemných pocitov ako je smútok a depresivita oproti pacientom $\mathrm{s}$ nízkou adherenciou k liečbe (Han et al., 2020).

Libanonská štúdia sa venovala adherencii u pacietnov s vysokým rizikom cievnej mozgovej príhody. Výskumný súbor tvorilo 174 pacientov u ktorých bolo identifikované riziko výskytu CMP. Premenné boli merané prostredníctvom 14 položkovej Libanonskej škály adherencie k medikácii a objektívnych ukazovatel'ov zdravia (krvného tlaku, úrovne cholesterolu v krvi). Výsledky tejto štúdii ukázali, že vysoká adherencia k medikamentóznej liečbe súvisí so znížením rizika cievnej mozgovej príhody u pacientov identifikovaných ako rizikových (Hajj, 2020).

Výskum uskutočnený na Nórskej populácii sa zameriaval na to, ako adherencia k medikamentóznej liečbe súvisí s rekonvalescenciou po prekonaní CMP. Štúdie sa zúčastnilo 380 pacientov. Premenné boli merané prostredníctvom Škály hodnotenia motoriky - Motor Assessment Scale (MAS), test chôdze - Time Up and Go (TUG), Bergovvou škálou rovnováhy - Begr Balance Scale (BBS), Škála dopadu cievnej mozgovej príhody - Stroke Impact Scale (SIS). Výsledky ukázali, že vyššia adherencia k liečbe súvisí so zlepšením motorického stavu, rovnováhy a pocitovaného funkčného stavu pacientov 6 mesiacov po prekonaní cievnej mozgovej príhody (Gunnes, 2019).

Tabul'ka č.2: Prehl'ad výskumov adherencie a rekonvalescencie po CMP.

\begin{tabular}{|l|l|l|}
\hline Autori: & $\begin{array}{l}\text { Vzorka, meracie nástroje, doba } \\
\text { merania po CMP : }\end{array}$ & Typ štúdie a hlavné zistenia: \\
\hline $\begin{array}{l}\text { Cheiloudaki } \\
\text { Alexopoulos, } \\
\text { (2019), Grécko }\end{array}$ & $\begin{array}{l}\text { N=180 } \\
\text { Medication Adherence Report } \\
\begin{array}{l}\text { Scale, Stroke Specific Quality of Life } \\
\text { Questionnaire } \\
\text { Doba: 24 týždňov po prekonaní } \\
\text { CMP }\end{array}\end{array}$ & $\begin{array}{l}\text { Korelačná } \\
\text { Optimálna adherenciou k liečbe } \\
\text { puroblémov vo vizuálne oblasti, } \\
\text { psychickej oblasti a v kognitívnej } \\
\text { oblasti }\end{array}$ \\
\hline
\end{tabular}




\begin{tabular}{|c|c|c|}
\hline $\begin{array}{l}\text { Han et al., (2020), } \\
\text { Brunej }\end{array}$ & $\begin{array}{l}\text { N=76 } \\
\text { Morisky scale of adherence, } \\
\text { Life-Style Questionnaire } \\
\text { Doba: } 24 \text { týždňov po prekonaní } \\
\text { CMP }\end{array}$ & $\begin{array}{l}\text { Komparačná } \\
\text { Pacienti s vyššou adherenciou k } \\
\text { liečbe vykazovali zlepšenie } \\
\text { životného štýlu, menej nežiaducich } \\
\text { účinkov súvisiacich s medikáciou } \\
\text { oproti pacientom s nízkou } \\
\text { adherenciou ku liečbe. }\end{array}$ \\
\hline $\begin{array}{l}\text { Hajj, } \\
\text { Libanon }\end{array}$ & $\begin{array}{l}\text { N=174 } \\
\text { Lebanese Medication Adherence } \\
\text { Scale-14 } \\
\text { Objektívne ukazovatele zdravia } \\
\text { (krvný tlak, hladina cholesterolu v } \\
\text { krvi) } \\
\text { Doba: - }\end{array}$ & $\begin{array}{l}\text { Korelačná } \\
\text { Vysoká adherencia } \\
\text { medikamentóznej liečbe súvisí so } \\
\text { znížením rizika cievnej mozgovej } \\
\text { príhody }\end{array}$ \\
\hline $\begin{array}{l}\text { Gunnes, (2019), } \\
\text { Nórsko }\end{array}$ & $\begin{array}{l}\mathrm{N}=380 \\
\text { Motor Assessment Scale, Walk Test } \\
\text { Time Up and Go, Berg Balance Scale, } \\
\text { Stroke Impact Scale (SIS) } \\
\text { Doba: } 12 \text { týždňov po prekonaní } \\
\text { CMP }\end{array}$ & $\begin{array}{l}\text { Korelačná } \\
\text { Vyššia adherencia k liečbe súvisí so } \\
\text { zlepšením motorického stavu, } \\
\text { rovnováhy a pocit'ovaného } \\
\text { funkčného stavu. }\end{array}$ \\
\hline
\end{tabular}

Výsledky štúdií realizované $\mathrm{v}$ posledných rokoch ale aj staršie štúdie, dlhodobo a pomerne konzistentne vykazujú pozitívny efekt adherentného správania na funkčný stav, zdravotný stav, self-management a zníženie rizika d’alšej cievnej mozgovej príhody a prípadných nežiaducich účinkov liekov oproti non-adherentnému správaniu.

\subsection{Sociálna opora a rekonvalescencia po prekonaní CMP}

Americká psychologická asociácia charakterizuje sociálnu oporu, ako poskytovanie pomoci alebo sprostredkovanie pohodlia iným, zvyčajne s ciel'om pomôct' im vyrovnat' sa s biologickými, psychologickými a sociálnymi stresormi. (APA, 2021). Sociálnu oporu teda môžeme chápat' ako akýkol'vek zdroj, ktorý prechádza sociálnymi vzt’ahmi (Waite, 2018). Tieto vzt’ahy sú založené na sociálnych interakciách, ktoré môžu byt' virtuálne, imaginované, reálne, krátkodobé aj dlhotrvajúce.

Sociálna opora môže z hl'adiska zdroja vyvstat' z akéhokol'vek medzil'udského vzt'ahu v sociálnej sieti jednotlivca. Najčastejšie sociálnu oporu poskytujú členovia rodiny, rodičia, partneri, deti, ale aj priatelia, susedia, náboženské organizácie, kolegovia, opatrovníci, odborníci ako sú lekári, zdravotníci ale aj umelo vytvorené podporné a terapeutické skupiny.

Z hl'adiska štruktúry identifikoval J. House (1988) zložky, ktoré môže sociálna opora obsahovat', uvádzame aj praktické ukážky 
Tabul'ka č.3: Zložky sociálnej opory a praktické ukážky

\begin{tabular}{|l|l|}
\hline \multicolumn{2}{|c|}{$\begin{array}{c}\text { Praktické ukážky zložiek sociálnej opory: } \\
\text { Peter je ženatý, } 62 \text { ročný muž s dvoma dospelými det'mi, ktorý pred } 3 \text { mesiacmi prekonal } \\
\text { cievnu mozgovú príhodu }\end{array}$} \\
\hline Emocionálna & $\begin{array}{l}\text { Petrova manželka a deti sa s ním rozprávajú o jeho obavách, aktívne ho } \\
\text { počúvajú a dodávajú mu nádej. }\end{array}$ \\
\hline Hodnotiaca & $\begin{array}{l}\text { Petrova dcéra sa o neho vel'mi bojí, často mu hovorí čo pre ňu znamená, } \\
\text { ako ho obdivuje ako celú situáciu zvláda a plánuje s ním po zlepšení } \\
\text { stavu dovolenku aj s jej manželom a det'mi. }\end{array}$ \\
\hline Informačná & $\begin{array}{l}\text { Doktori sa s Petrom dohodli na pravidelných stretnutiach na ktorých ho } \\
\text { informujú o dôvodoch najbližších krokov pre zlepšenie jeho } \\
\text { zdravotného stavu a konzultujú s ním dôležité aspekty životného štýlu. }\end{array}$ \\
\hline Inštrumentálna & $\begin{array}{l}\text { Petrov syn, ktorý žije v tom istom meste, si dva dni v týždni vybavil } \\
\text { homeoffice, aby ho mohol vozit' na rehabilitáciu ked’že jeho motorika } \\
\text { vyžaduje pravidelné cvičenie. }\end{array}$ \\
\hline
\end{tabular}

Kebza (2005) doplňuje okrem 4 základných zložiek a dve okrajové, ktoré sa však mnoho krát vyskytujú:

1. Sociálna opora spočívajúca vo vedení - Tzv. "Guidance support", kedy je poskytovatel' akýmsi sprievodcom alebo mentorom prijímatel'a, bud' v nových alebo náročných časoch.

2. Socializačná opora - spočíva v napomáhaní začleneniu sa do nový spoločenských vrstiev alebo špecifických sociálnych skupín.

Novým fenoménom, ktoré priniesol rozvoj moderných technológií je online sociálna opora. Online komunity a skupiny ktoré sa venujú oblasti zdravia, ponúkajú nové príležitosti na poskytovanie aj prijímanie sociálnej opory prostredníctvom diskusných fór, chatovacích miestností a blogov (Coulson et al., 2007; Mo \& Coulson, 2008; Sarasohn-Khan, 2008; Idriss et al. 2009; Malik \& Coulson, 2008). Medzi potenciálne výhody patrí prístup k mnohým osobným skúsenostiam iných pacientov s rovnakými zdravotnými problémami, pohodlná komunikácia aj napriek vel'kým geografickým vzdialenostiam, anonymita v diskusiách o citlivých a intímnych problémoch (White \& Dorman, 2001; Writh \& Bell, 2003). Online komunity predstavujú špecifický priestor v ktorom sa l’udia so spoločnými záujmami a názormi pravidelne stretávajú vymieňajú si informácie (IPčko, 2016). Tieto faktory kopírujú takmer všetky zložky sociálnej opory.

- Nachádzajú sa tam l’udia, ktorí na seba vzájomne vplývajú v záujme vlastných potrieb alebo v komunite zastávajú špecifické úlohy.

- Zdiel'ajú spoločný účel a ciel', ako napríklad záujmy, potreby, výmenu informácií alebo službu, ktorá dáva online skupine dôvod existovat'

- Nachádzajú sa tam postupy, ktoré riadia vzájomnú interakciu l’udí

- Komunikácia prebieha vd'aka počítačovému systému ktorý podporuje a sprostredkúva sociálne interakcie a ul'ahčuje vytváranie pocitu jednoty

Sociálna opora bola v posledných desat'ročiach rozsiahlo skúmaná (Uchino, 2004; Gottlieb \& Bergen, 2010). Longitudinálne štúdie o súvislosti vnímanej sociálnej opory na zdravie jednotlivca 
hovoria, že kvalitné sociálne zázemie preukázatel'ne znižuje riziko kardiovaskulárnych chorôb (Anthony \& O'Brien, 1999; Havranek et al., 2015; Ginting et al., 2016), respiračných chorôb (Cohen et, al. 2015; Deverts et a., 2015), cievnej mozgovej príhody (Valtorta et al., 2016) a iných chorôb. Z výsledkov empirických štúdií sa zdá že sociálna opora dokonca znižuje mieru úmrtnosti. Nedávna metaanalýza 148 nezávislých štúdií naznačuje, že sociálne vzt’ahy sú významnými prediktormi úmrtnosti a odhal'ujú silný vplyv sociálnej opory na dlhovekost' a celkovú spokojnost' so životom (Holt-Lunstad et al., 2010, 2015).

Americká longitudinálna štúdia venujúca sa vplyvu sociálnej opory na rekonvalescenciu pacientov po prekonaní cievnej mozgovej príhody potvrdila jej významnost'. Do výskumu bolo zaradených 46 pacientov, ktorí boli sledovaní po dobu 6 mesiacov. Meranie prebehlo v 1., 3., a 6 . mesiaci. Premenné boli merané prostredníctvom inventára správania sociálnej opory - The Inventory of Socially Supportive Behaviors (ISSB) a Barthelovho indexu každodenných aktivít - Barthel Index (BI) of activities of daily living (ADL). Záverom bolo, že vysoká miera sociálnej opory bola spojená s rýchlejšou a rozsiahlejšou rekonvalescenciou a obnovením funkčného stavu pacientov po cievnej mozgovej príhode. Sociálna opora sa teda ukázala byt' dôležitým prognostickým faktorom pri zotavení po cievnej mozgovej príhode. Sociálne izolovaní pacienti môžu byt' vystavení riziku nepríjemných následkov a opakovaním príhod (Glass et al., 1999).

Na Gréckej vzorke pacientov po prekonaní CMP sa ukázali podobné rozdiely. Výskumnú vzorku longitudinálnej štúdie tvorilo 43 pacientov fakultnej nemocnice v Aténach. Zber dát prebiehal v troch etapách v 1., 3. a 6. mesiaci rovnako ako v predchádzajúcom prípade. Premenné boli merané pomocou Barthelovho indexu každodenných aktivít - Barthel Index (BI) of activities of daily living (ADL) a škálou sociálnej opory rodiny - Family Social Support Scale (FSSS). Výsledky ukázali, že vysoká úroveň rodinnej sociálnej opory (inštrumentálna a emocionálna) súvisí s postupným zlepšovaním funkčného stavu pacientov t’ažko zasiahnutých CMP (Tsouna-Hadjis et al., 2000).

Nedávna štúdia realizovaná v Nigérii podporuje konzistenciu teoretických modelov a doterajších empirických zistení. Skúmanie sa zameralo na účinnost' sociálnej opory pri zvládaní dôsledkov cievnej mozgovej príhody. Dáta boli zbierané pomocou meracích nástrojov: Dotazníka sociálnej opory a Multidimenzionálnou škálou sociálnej opory - Multidimensional Scale of Social Support a dotazníka self-managementu po CMP - Stroke self-management questionnaire (SS-MQ). Výskumnú vzorku tvorilo 50 pacientov štátnej nemocnice Adeoyo, ktorí prekonali CMP (Blessing \& Oluwagbemiga, 2017).

Výsledky ukázali, že pri zvládaní zdravotných dôsledkov cievnej mozgovej príhody sú najdôležitejšie faktory sociálnej opory: Rodinnej opory $(r=0,352, p=0,05)$, Finančnej opory $(0,658$, $0,05)$, Emocionálnej opory $(r=0,402, p=0,05)$, Spolupatričnosti $(r=0,787, p=0,05)$. Štúdia dokázala, že zvládanie zdravotných problémov po prekonaní CMP si vyžaduje zapojenie sociálnej podpory pacienta - rodinnej, finančnej, emocionálnej a tiež spolupatričnost' pre efektívnejšiu adaptáciu a vyrovnanie sa so zdravotnými dôsledkami CMP (Blessing \& Oluwagbemiga, 2017) 
Tabul'ka č.4: Prehl'ad výskumov sociálnej opory a rekonvalescencie po CMP.

\begin{tabular}{|c|c|c|}
\hline Autori: & $\begin{array}{l}\text { Vzorka, meracie nástroje, doba } \\
\text { merania po CMP : }\end{array}$ & Typ štúdie a hlavné zistenia: \\
\hline $\begin{array}{l}\text { Blessing, } \\
\text { Oluwagbemiga } \\
(2017) \\
\text { Nigéria }\end{array}$ & $\begin{array}{l}\mathrm{N}=50 \\
\text { Multidimensional Scale of Social } \\
\text { SupportScale, } \\
\text { Stroke self-management } \\
\text { questionnaire (SS-MQ) } \\
\text { Doba:- }\end{array}$ & $\begin{array}{l}\text { Korelačný } \\
\text { Rodinná, finančná, emocionálna } \\
\text { opora a spolupatričnost'vykazovala } \\
\text { pozitívny vzt'ah s adaptácioua } \\
\text { vyrovnávaním sa so zdravotnými } \\
\text { dôsledkami CMP. }\end{array}$ \\
\hline $\begin{array}{l}\text { Tsouna-Hadjis et al. } \\
(2000) \\
\text { Grécko }\end{array}$ & $\begin{array}{l}\mathrm{N}=43 \\
\text { Family Social Support Scale, } \\
\text { Barthel index } \\
\text { Doba: 4.,8., a } 24 \text { týždňov po } \\
\text { prekonaní CMP }\end{array}$ & $\begin{array}{l}\text { Longitudinálny, Komparačný } \\
\text { U pacientov s vysokou } \\
\text { Inštrumentálnou a Emocionálnou } \\
\text { oporou zo strany rodiny bola miera } \\
\text { rekonvalescencie signifikantne vyššia } \\
\text { než už pacientov s nízkou oporou. } \\
\text { Najvýraznejšie sa tieto rozdiely } \\
\text { ukazovali u t'ažko zasiahnutí pacienti. }\end{array}$ \\
\hline $\begin{array}{l}\text { Glass, et al. (1999) } \\
\text { USA }\end{array}$ & $\begin{array}{l}\mathrm{N}=46 \\
\text { Inventory of social support scale, } \\
\text { Barthel index } \\
\text { Family Social Support Scale, } \\
\text { Barthel index } \\
\text { Doba: } 4 ., 8 ., \text { a } 24 \text { týždňov po } \\
\text { prekonaní CMP }\end{array}$ & $\begin{array}{l}\text { Longitudinálny,Korelačno- } \\
\text { komparačný: } \\
\text { Miera rekonvalescencie pacientov po } \\
\text { CMP s vysokou úrovňou sociálnej } \\
\text { opory bola signifikantne vyššia a } \\
\text { rýchlejšia ako u sociálne izolovaných } \\
\text { pacientov }\end{array}$ \\
\hline
\end{tabular}

Na základe teoretických a empirických výstupov možno konštatovat', že adekvátna sociálna opora poskytuje pacientom dôležité východiskové zázemie ktoré umožňuje zvládnut' a rýchlo sa zotavit' z dôsledkov tohto závaného ochorenia. Nesmierne dôležitú čast' sociálnej siete pacientov predstavuje rodina, priatelia, lekári, zdravotnícky personál, spolupracovníci, susedia a d’alšie významné osoby ktoré sprostredkujú emočnú, finančnú, inštrumentálni oporu a spolupatričnost’a tak ul'ahčujú pacientom po prekonaní CMP zvládnut' a rýchlo sa zotavit' zo svojho ochorenia.

\section{DISKUSIA}

Ochorenia súvisiace s ochorením kardiovaskulárneho systému predstavujú dlhodnobý závažný spoločenský a ekonomický problém (OECD,2015; ECDS, 2017). Je teda spoločenskou protebou a nutnost'ou hl'adat' riešenia ako sa s ním vysporiadat'. Okrem faktorov životného štýlu a štandardnej medikamentóznej liečby sa ukazuje, že niektoré psychologické premenné zohrávajú klúčovú rolu v predchádzaní vzniku kardiovaskulárnych ochorení a v efektívnej rekonvalescencii po ich vypuknutí.

Ciel'om našej prehl'adovej štúdie bolo poskytnút' bližší pohl'ad na to ako sa premenné umiestnenia kontroly vo vzt'ahu k zdraviu, adherencie k liečbe a sociálna opora podpisujú na efektivite rehabilitácie, rekonvalescencie a funkčnom stave pacientov po prekonaní cievnej mozgovej príhody. Na základe analyzovania výskumov v tejto oblasti možno konštatovat': 
1. Umiestnenie kontroly vo vzt’ahu k zdraviu stále prináša zmiešané výsledky o tom, ktorý faktor stojí za efektívnejším zotavením sa po cievnej mozgovej príhode. Nedávne štúdie skôr poukazujú na Interné umiestnenie kontroly ako na preventívny faktor CMP, ale aj pozitívny činitel' po vypuknutí ochorenia. Interné umiestnenie kontroly súvisí s efektívnym zotavením sa, zlepšením funkčného stavu pacientov, samostatnosti a nezávisosti na pomoci blízkych alebo opatrovatel’ov. Je však nutné priniest' viac dôkazov o tomto trende.

2. Adherencia k medikamentóznej liečbe sa dlhodobo ukazuje ako dôležitých faktor v liečbe a rekonvalescencii. Za rizikový sa ukazuje vek, kedy u mladších pacientov dochádza $\mathrm{k}$ dodržiavaniu liečby stanovenej lekárom. Optimálne adherentné súvisí so zlepšením funkčného stavu - motorickej, emočnej, kognitívnej oblasti, rovnováhy a nižším rizikom CMP a nižším výskytom problémov v zrakovej oblasti. Pacienti s adherentným správaním vykazovali tiež menej nežiaducich účinkov medikamentov.

3. Sociálna opora vykazuje jasné výsledky z hl'adiska jej súvislosti so zdravotným stavom pacientov po prekonaní CMP. Ukazuje sa že rodina, priatelia, blízke osoby ale aj odborníci a ich opora sa významne podiel'ajú na efektivite rekonvalescencie a rýchlejšom zotavení. Tento trend sa ukazuje predovšetkým pri inštrumentálnej, emočnej, finančnej podpore a tiež spolupatričnosti.

Efektívne a kvalitné zotavenie po závažnom ochorení je nesmierne dôležité pre budúce smerovanie a kvalitu života pacientov. Aktívnym skúmaním premenných, ktoré súvisia so vznikom kardiovaskulárnych ochorení medzi nimi aj cievnej mozgovej príhody a aplikáciou ich výsledkov do praxe môžeme vrátit' ich nepríjemné zdravotné a ekonomické dopady na jednotlivca a spoločnost'.

\section{ZÁVER}

Ukazuje sa, že nie len medicínske a rehabilitačné postupy umožňujú rekonvalescenciu pacientov. Výsledky prezentovaných štúdií hovoria o psychologických premenných ( $\mathrm{v}$ našom prípade umiestnenia kontroly, adherencie a sociálnej opory), ktoré značnou mierou prispievajú ku funkčnému zotaveniu pacientov po prekonaní cievnej mozgovej príhody. Je preto nutné nad'alej pokračovat'v ich skúmaní a aplikáciou do praxe.

\section{LITERATÚRA}

Anthony, J. L. \& O'Brien, W. H. (1999). An evaluation of the impact of social support manipulations on cardiovascular reactivity to laboratory stressors. Behavioral Medicine 25, 78-87. doi: 10.1080/08964289909595740

Ali, S. M. \& Lindström, M. (2006). Socioeconomic, psychosocial, behavioural, and psychological determinants of BMI among young women: Differing patterns for underweight and overweight/obesity. European Journal of Public Health, 16(3), 324-330

APA. (2021). APA Dictionary of Psychology. [online] Available at: $<$ https://dictionary.apa.org/social-support> [Accessed 24 May 2021].

Booker, C.S., \& Mann, J.I. (2008). "Trans fatty acids and cardiovascular health: translation of the evidence base". Nutrition, Metabolism, and Cardiovascular Diseases. 18 (6): 448-56. doi:10.1016/j.numecd.2008.02.005. PMID 18468872. 
Blessing, M. \& Oluwagbemiga, O. (2017). Effectiveness of Social Support in Coping with Stroke by Medically Ill Patient in Ibadan. International Journal of Neurorehabilitation, 04(04). doi:10.4172/2376-0281.1000281

Bucholz, E. M., Strait, K. M., Dreyer, R. P., Geda, M., Spatz, E. S., Bueno, H. \& Krumholz, H. M. (2014). Effect of Low Perceived Social Support on Health Outcomes in Young Patients With Acute Myocardial Infarction: Results From the VIRGO (Variation in Recovery: Role of Gender on Outcomes of Young AMI Patients) Study. Journal of the American Heart Association, 3(5), e001252e001252. doi:10.1161/jaha.114.001252

Cheiloudaki, E. \& Alexopoulos, E.C. (2019). Adherence to Treatment in Stroke Patients. International Journal Environmental Research Public Health. 2019 Jan 11;16(2):196. doi: 10.3390/ijerph16020196. PMID: 30641978; PMC: 6351941.

Chen, Z., Fan, V.S., Belza, B., Pike, K. \& Nguyen, H.Q. (2017). Association between Social Support and Self-Care Behaviors in Adults with Chronic Obstructive Pulmonary Disease. Annals of American Thoracic Society. 2017 Sep;14(9):1419-1427. doi: 10.1513/AnnalsATS.201701-0260C. PMID: $28719225 ;$ PMC5711401.

Cohen, S., Janicki-Deverts, D., Turner, R. B. \& Doyle, W. J. (2015). Does hugging provide stressbuffering social support? A study of susceptibility to upper respiratory infection and illness. Psychological Science. 26, 135-147. doi: 10.1177/0956797614559284

Cohen, B.E., Edmondson D. \& Kornish I.M. (2015). State of the Art Review: Depression, Stress, Anxiety, and Cardiovascular Disease. American Journal of Hypertension. 28 (11): 1295-1302. doi:10.1093/ajh/hpv047. PMC 4612342. PMID 25911639.

Costa-Cordella, S., Arevalo-Romero, C., Parada, F. J. \& Rossi, A. (2021). Social Support and Cognition: A Systematic Review. Frontiers in psychology, 12, 637060. https://doi.org/10.3389/fpsyg.2021.637060

Coulson, N.S., Buchanan, H. \& Aubeeluck, A. (2007). Social support in cyberspace: a content analysis of communication within a Huntington's disease online support group. Patient Education and Counseling. 2007;68(2):173-178.

Crayton, E., Wright, A. J. \& Ashworth, M. (2018). Improving medication adherence in stroke survivors: the intervention development process. BMC health services research, 18(1), 772. https://doi.org/10.1186/s12913-018-3572-1

Deverts, D., Cohen, S., Doyle, W.J. (2015). Dispositional Affect Moderates the Stress-Buffering Effect of Social Support on Risk for Developing the Common Cold. Journal of Personality. 2015 Oct; 85(5):675-686.

Deary, I. J., Weiss, A. \& Batty, G. D. (2010). Intelligence and personality as predictors of illness and death: How researchers in differential psychology and chronic disease epidemiology are collaborating to understand and address health inequalities. Psychological Science in the Public Interest, 11, 53-79.

ECDS, - Wilkins E., Wilson L., Wickramasinghe K., Bhatnagar P., Leal J., Luengo-Fernandez R., Burns R. \& Rayner M, Townsend N., (2017). European Cardiovascular Disease Statistics 2017. European Heart Network, Brussels.

Fu, H., Kaminga, A.C. \& Peng, Y. (2020). Associations between disease activity, social support and health-related quality of life in patients with inflammatory bowel diseases: the mediating role of 


\section{Pomáhajúce profesie, roč. 4, č. 1, 2021, 14-29}

psychological symptoms. BMC Gastroenterol 20, 11 (2020). https://doi.org/10.1186/s12876-0201166-y

Ginting, H., van de Ven, M., Becker, E.S. \& Näring, G. (2016). Type D personality is associated with health behaviors and perceived social support in individuals with coronary heart disease. Journal of Health Psychology, 2016 May; 21(5):727-37.

Gore, J. S., Griffin, D. P. \& McNierney, D. (2016). Does Internal or External Locus of Control Have a Stronger Link to Mental and Physical Health? Psychological Studies, 61(3), 181-196.

Grodner, S., Prewitt, L.M. \& Jaworsk, B.A., (2016). The impact of social support in pulmonary rehabilitation of patients with chronic obstructive pulmonary disease. Annals of Behavioral Medicine 1996;18(3):139-45.

Gottlieb, B. H. \& Bergen, A. E. (2010). Social support concepts and measures. Journal of Psychosomatic Research,. 69, 511-520. doi: 10.1016/j.jpsychores.2009.10.001

Glass, T.A., Matchar, D.B., Belyea, M. \& Feussner, J.R.,(1993). Impact of social support on outcome in first stroke. Stroke. 1993 Jan;24(1):64-70. doi: 10.1161/01.str.24.1.64. PMID: 8418553.

Gunnes, M., Indredavik, B., Langhammer, B., Lydersen, S., Ihle-Hansen, H., Dahl, A. E. \& Askim, T., (2019). Associations Between Adherence to the Physical Activity and Exercise Program Applied in the LAST Study and Functional Recovery After Stroke. Archives of physical medicine and rehabilitation, 100(12), 2251-2259. https://doi.org/10.1016/j.apmr.2019.04.023

Hamzah, A. Sugiyanto. (2014). Strengthening of Health Locus of Control could Increase the Independence of Post Stroke Patients in Implementing the Daily Activities at Home. Journal of Nursing and Care 3: 152. DOI: http://dx.doi.org/10.4172/2167-1168.1000152

Han, Y. K. , Rajabalaya, R., D.K., Hajah Norazieda Binti P.G. \& H.J. Mohammad Yassin, Sheba, R., David, Medication adherence in stroke patients in Brunei Darussalam Public Hospital: the crosssectional study associated with chronic diseases, lifestyle and potential barriers, Journal of Pharmaceutical Health Services Research, Volume 11, Issue 2, June 2020, pp. 127-132, https://doi.org/10.1111/iphs.12335

Havranek, E. P., Mujahid, M. S., Barr, D. A., Blair, I. V., Cohen, M. S. \& Cruz-Flores, S. (2015). Social determinants of risk and outcomes for cardiovascular disease: a scientific statement from the American Heart Association. Circulation 132, 873-898. doi: 10.1161/CIR.0000000000000228

Hajj, M., Ajrouche, R., Zein, S., Rachidi, S., Awada, S. \& Al-Hajje, A. (2020). Evaluation of risk factors and drug adherence in the occurrence of stroke in patients with atrial fibrillation. Pharmacy Practice, 18(2), 1860. doi:10.18549/pharmpract.2020.2.1860

Holt-Lunstad, J., Smith, T. B., Baker, M., Harris, T. \& Stephenson, D. (2015). Loneliness and social isolation as risk factors for mortality: a meta-analytic review. Perspective on Psychological Science. 10, 227-237. doi: $10.1177 / 1745691614568352$

Holt-Lunstad, J., Smith, T. B. \& Layton, J. B. (2010). Social relationships and mortality risk: a metaanalytic review. PLoS Medicine 7:e1000316. doi: 10.1371/journal.pmed.1000316

House, J., Umberson, D. \& Landis, K.R. (1988). Structures and Processes of Social Support. Review of Sociology, 14, 293-318.

Idriss, S.Z., Kvedar, J.C. \& Watson, A.J. (2009). The role of online support communities: benefits of expanded social networks to patients with psoriasis. Archives of Dermatology 2009;145(1):46-51. 
Jomeen, J. \& Martin, C. R. (2005). A psychometric evaluation of form C of the Multi-dimensional Health Locus of Control (MHLC-C) Scale during early pregnancy. Psychology, Health \& Medicine, 10(2), 202-214.

Kebza, V., 2005. Psychosociální determinanty zdraví. Praha: Academia, 263 s. ISBN 80-200-1307-5.

Kim, Y. (2011). Adolescents' Health Behaviours and it's Associations with Psychological Variables. Central European Journal of Public Health, 19 (4), 205-209

Kupper, N. \& Denollet, J. (2018). Type D Personality as a Risk Factor in Coronary Heart Disease: a Review of Current Evidence. Current Cardiology Reports. 2018;20(11):104. Published 2018 Sep 12. doi:10.1007/s11886-018-1048-x

Ládová, K., (2015) Význam hodnocení adherence $k$ léčbě pomocí výpovědi pacienta $v$ posouzení účinnosti farmakoterapie, Dizertační práce, Hradec Králové: Univerzita Karlova Praha, Farmaceutická fakulta v Hradci Králové, Katedra sociální a klinické farmacie, 2015. 96 s.

Lenferink, A., van der Palen, J. \& Effing, T. (2018). The role of social support in improving chronic obstructive pulmonary disease self-management. Expert Review of Respiratory Medicine, 12(8), 623-626. doi:10.1080/17476348.2018.1489723

Lei, T.T., Han, H.M. \& Liu, X.J. (2020). The multiple mediation effects of health locus of control and hope on the relationship between social support and self-management in stroke patients. Frontiers of Nursing. 2020; 1: 49-58.

Malik, S.H. \& Coulson, N.S. (2008). Computer-mediated infertility support groups: an exploratory study of online experiences. Patient Education and Counseling. 2008;73(1):105-113.

Mendis, S., Puska P. \& Norrving, B. (2011). Global Atlas on Cardiovascular Disease Prevention and Control (PDF). World Health Organization in collaboration with the World Heart Federation and the World Stroke Organization. pp. 3-18. ISBN 978-92-4-156437-3.

Moreira, Carmelita Naiara de Oliveira (2016). Health locus of control, spirituality and hope for healing in individuals with intestinal stoma. Journal of Coloproctology (Rio de Janeiro) [online]. 2016, v. 36, n. 4 , pp. 208-215. ISSN 2317-6423. https://doi.org/10.1016/j.jcol.2016.04.013

Mo, P.K.H. \& Coulson, N.S. (2008). Exploring the communication of social support within virtual communities: a content analysis of messages posted to an online HIV/AIDS support group. CyberPsychology and Behavior. 2008;11(3), pp:371-374.

Nakamoto, K.,Schulz, P. J. \& Náfrádi, L.,(2017). Is patient empowerment the key to promote adherence? A systematic review of the relationship between self-efficacy, health locus of control and medication adherence. PloS one, 12(10), e0186458. https://doi.org/10.1371/journal.pone.0186458

Ozcakir, A.,. Dogan, F. O., Bayram, N. \& Bilgel1, N.(2014). Health Locus of Control, Health Related Behaviors and Demographic Factors: A Study in a Turkish Population. British Journal of Medicine \& Medical Research, 4(21): 3856-3869, 2014.

Omeje, O. \& Nebo, C., (2001). The influence of locus of control on adherence to treatment regimen among hypertensive patients. Patient preference and Adherence. 2011. 141-148.

Pishkhani, M.K., Dalvandi, A., Ebadi, A. \& Hosseini, M.A., (2020). Adherence to a Rehabilitation Regimen in Stroke Patients: A Concept Analysis. Iranian Journal of Nursing Midwifery Research 2020;25:139-45 
Rapoliené, J., Endzelyté, E., Jasevičenié, I. \& Savickas, R., (2018) Stroke patients motivation influence on the effectiveness of occupational therapy, Rehabilitation Research and Practice, Vol. 2018, p. 87- 95, https://doi.org/10.1155/2018/9367942

Reid, D.W. \& Ware, E. E. (1973). Multidimensionality of internal-external control: Implications for past and future research. Canadian Journal of Behavioral Science, 1973, 5, 264-271.

Sarasohn-Kahn, J. (2008). The wisdom of patients: Health care meets online social media. [Accessed June, 1., 2021]. available at http://www.chcf.org/documents/chronicdisease/HealthCareSocialMedia.pdf.

Steptoe, A. \& Chida, Y. (2009). The association of anger and hostility with future coronary heart disease: a meta-analytic review of prospective evidence. Journal of the American College of Cardiology, 53, 936-946.

Steptoe, A., Wardle, J. (2001). Locus of control and health behaviour revisited: A multivariate analysis of young adults from 18 countries. British Journal of Psychology, 92(4), 659-672. doi:10.1348/000712601162400

Tsouna-Hadjis E, Vemmos K.N, Zakopoulos N. \& Stamatelopoulos S. (2000). First-stroke recovery process: the role of family social support. Archives of Physical Medicine and Rehabilitation. 2000., Jul;81(7):881-887. doi: 10.1053/apmr.2000.4435. PMID: 10895999.

Taher, M, Safavi, Bayat, Z., Niroomand Zandi, K., Ghasemi, E., Abredari, H., Karimy, M. \& Abedi, A.R. (2015) Correlation between compliance regimens with health locus of control in patients with hypertension. Medicine Journal of The Islam Republic Iran. 2015 (18 March). Vol. 29:194.

Uchino, B. N. (2004). Social Support and Physical Health: Understanding the Health Consequences of Relationships. New Haven, CT; London: Yale University Press.

Usta, Y.Y., 2012, Importance of social support in cancer patients. Asian Pacific Journal of Cancer Prevention. 2012; 13(8): 3569-3572. doi: 10.7314/apjcp.2012.13.8.3569. PMID: 23098436.

Valtorta N. K., Kanaan M., Gilbody S., Ronzi S. \& Hanratty B. (2016). Loneliness and social isolation as risk factors for coronary heart disease and stroke: systematic review and meta-analysis of longitudinal observational studies. Heart 102, 1009-1016. 10.1136/heartjnl-2015-308790

Vráblik, M., (2012). Adherence v léčbě hypertenze: Pomohou nové lékové formy. Interní medicína pro prax. 2012; 14(11) s. 415-218)

Wallston, K. A., Wallston, B. S. \& Devellis, R. (1978). Development of the multidimensional health locus of control (MHLC) scales. Health Education Monographs, 6, 160-170.

Waite, L. J. (2018). "Social well-being and health in the older population: moving beyond social relationships," in Future Directions for the Demography of Aging: Proceedings of a Workshop (Washington DC: National Academies Press).

White, M. \& Dorman, S.M. (2001). Receiving social support online: implications for health education. Health Education and Research. 2001;16(6):693-707.

Wright, K.B. \& Bell, S.B. (2003). Health-related support groups on the Internet: linking empirical findings to social support and computer-mediated communication theory. Journal of Health Psychology 2003;8(1):39-54. 
World Health Organisation, (2003) Adherence in long-term therapies: evidence for action. [online]. 2003. [cit. 2021-30.-05]. Dostupné z: http://www.who.int/chp/knowledge/publications/adherence_report/en/.

Zirk, M. \& Storm, V. (2019) Subjective Stroke Impact and Depressive Symptoms: Indications for a Moderating Role of Health-Related Locus of Control. Frontiers in Psychiatry, December 2019. Vol. 10. (918), p. 4. https://doi.org/10.3389/fpsyt.2019.00918

Zulkifly, F. \& Ghazali, E. S., Normah, CH, D., Desa, A., Ali, R. B.A., (2015). The Ability of Recovery Locus of Control Scale (RLOC) and Post-traumatic Stress Symptoms (PTSS) to Predict the Physical Functioning of Stroke Patients. Malaysian Journal of Medical Sciences, Vol. 22. p. 31-41.

\title{
HEALTH LOCUS OF CONTROL, ADHERENCE TO MEDICATION, SOCIAL SUPPORT AND RECONVALESCENCE OF PATIENTS AFTER STROKE
}

\begin{abstract}
Cardiovascular diseases represents a serious problem in society. In addition to ischemic heart disease, the most common is also stroke. Its consequences affect the functioning of individuals and their quality of life, as well as the economic burden on states. It is therefore important to look for ways to prevent this problem or minimize its consequences. The review study focused on psychological assumptions: the location of control in relation to health, adherence, social support, as a factor related to the effectiveness of recovery after overcoming a stroke. Its aim was to analyze the effect of these variables in terms of theoretical background and recent empirical findings.
\end{abstract}

Key words: stroke, reconvalescence, locus of control, adherence, social support,

\section{Grantová podpora:}

Príspevok vznikol ako súčast' riešenia grantového projektu VEGA 1/0418/19: Zvládanie zát’aže v procese rekonvalescencie po cievnej mozgovej príhode a UGA IX/4/2021: Lokalizácia kontroly vo vzt'ahu k zdraviu ako psychologický faktor prevencie rizika vzniku kardiovaskulárnych ochorení.

Key words: coping, father's presence 